\title{
PERBANDINGAN PENYERAPAN UNSUR HARA OLEH TANAMAN PADI (Oryza Sativa.L ) DENGAN TANAMAN KACANG PANJANG ( Vigna sinensis ) YANG DITANAM PADA TANAH MENGGUNAKAN ICP-MS
}

\author{
Zulkarnain Chaidir.Abdi Dharma,Edison Munaf,Yunazar Manjang.Rahmiana Zein \\ Jurusan Kimia FMIPA Unand \\ Email : zulkarnain_ch@yahoo.co.id
}

\begin{abstract}
Comparative studies on nutrient uptake ability of rice plants (Oryza Sativa.L) that represent groups of plants dicotyledonous with long beans (Vigna sinensis) representative of the group of plants monocotyledonous have been conducted. The study was conducted on a community farm located in the Village of Sungai Sapih Padang, at plants are used as the sample is sokan varieties. The root of leaves and fruit as well as beans, the same parts are used as sample.

Morphological observations of roots, leaves and fruit using the SEM showed the difference between the rice and beans. While the homogenity for fruit rice and beans especially almost the same. The results of nutrient measurements performed by ICP - MS, elemental carbon is the largest percentage of nutrients in the two plants in average above $50 \%$ in all parts of the plant. The percentage of $\mathrm{Ca}, \mathrm{Mg}$ and $\mathrm{N}$ elements in the leaves of beans is higher than in the rice leaves, otherwise the percentage of $\mathrm{Si}$ element is higher in the rice plants.
\end{abstract}

Key words: absorption, nutrients, Oryza sativa, Vigna sinensis, ICP-MS

\section{DAFTAR PUSTAKA}

1. A. Munawar, Kesuburan Tanah Dan Nutrisi Tanaman, IPB PRESS, Bogor (2011).

2. D. Kachroo and R. Razdan, Growth, Nutrient Uptake And Yield Of Wheat (Triticum Aestivum) Asinfluenced by Biofertilizers and Nitrogen, Indian Journal of Agronomy 51 (1): 37-39 (2006).

3. J. A. Silva and R. Uchida, Plant Nutrient Management in Hawaii's Soils, Approaches for Tropical and Subtropical Agriculture University of Hawaii, Manoa, (2000).

4. Le Bot J, S. Adamowicz, P. Robin, Modelling Plant Nutrition Of Horticultural Crops: A Review. Sci. Hortic-Amsterdam, 74(1-2): 47-82. (1998).

5. R. Tuncturk and M. Tuncturk, Effects of Different Phosphorus Levels on The Yield and Quality Components of Cumin (Cuminum cyminum L.), Res. J. Agric. Biol. Sci., 2(6): 336-340 (2006).
6. K. Tamai and J.F. Ma, Characterization of Silicon Uptake by Rice Roots. New Phytol. 158, 431-436, (2003).

7. Roy U. Schenk, A. C. Hildebrandt, Medium and Ttechniques for Induction and Growth of Monocotyledonous and Dicotyledonous Plant Cell Cultures, Canadian Journal of Botany, Vol. 50, No. 1 : pp. 199-204 (1972).

8. Bacilio-Jiménez, M., S. Aguilar-Flores, E. Ventura-Zapata, E. Pérez-Campos, S. Bouquelet, and E. Zenteno, Chemical Characterization of Root Exudates from Rice (Oryza sativa) and Their Effects on the Chemotactic Response of Endophytic Bacteria, Plant Soil. 249:271-277. (2003). 
